\title{
EL ARTISTA COMO DICTADOR SOCIAL O EL POLÍTICO COMO ESCENÓGRAFO ${ }^{1}$
}

\section{Adolfo Vásquez Rocca*}

Universidad Andrés Bello - Universidad Complutense de Madrid

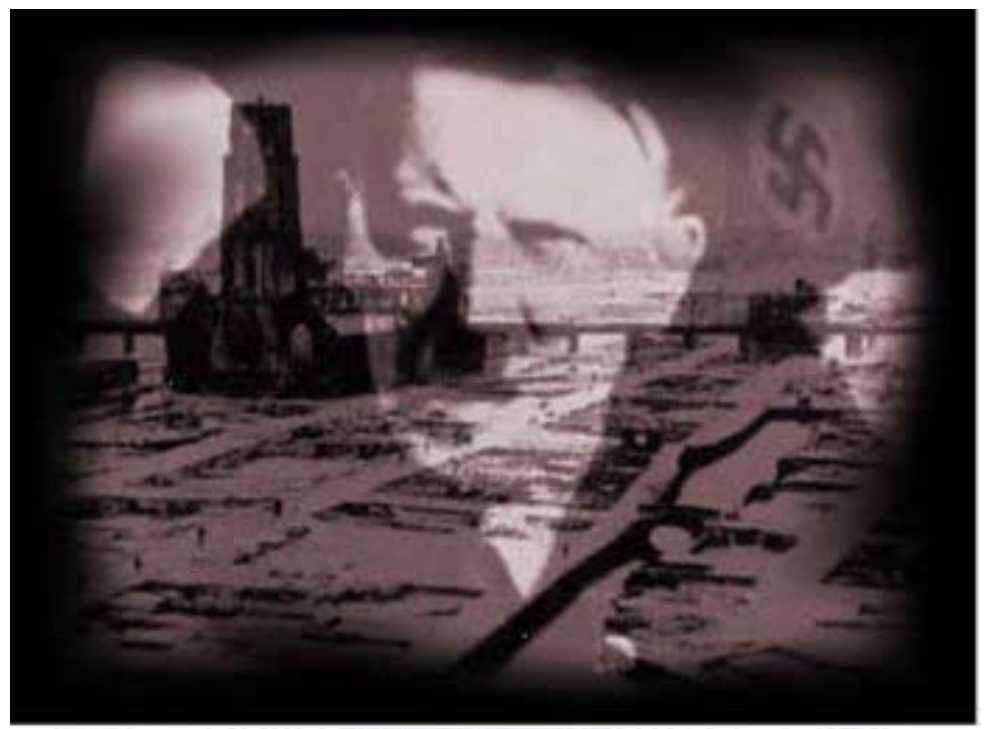

Resumen.- $\quad$ Sin duda el potencial iconográfico de la política nazi fue un aspecto esencial del éxito sobre un pueblo que no tardó en erigir a su Führer como el centro de su verdad y el sostén narcisístico de su imagen, con un precio muy alto a pagar. La realización paroxística de acciones de arte vanguardista, la hipnótica utilización de una iconografía que incluía no sólo las esvásticas; también los cascos de la Wehrmacht, cierta clase de botas, las cruces de hierro, etc. dan cuenta de una de las prácticas de manipulación habituales en la política de hoy, donde se prioriza lo mediático en desmedro del contenido programático. A la luz del impacto de los acontecimientos terroristas del 11 de septiembre de 2001 y su potencial iconográfico, parece resurgir el interés por repensar el fenómeno del nacionalsocialismo, el alcance ideológico-estético de los episodios históricos, donde el despliegue de una violencia maquinal parece concordar con algunos dichos y proclamas de las vanguardias de los años 20', así como con declaraciones de algunos pensadores filo-nazis como Heidegger que en una conferencia en Bremen en 1950 señaló que "la fabricación de cadáveres en las cámaras de gas y la transformación de la agricultura en industria alimenticia son en esencia lo mismo".

Palabras clave.- Arte vanguardista, estética nazi, estética terrorista, Adolf Hitler, 11 de septiembre, Biopolítica.

Este Artículo: "El artista como dictador social o el político como escenógrafo" corresponde al Proyecto de Investigación: $N^{\circ}$ DI-08-11/JM Fondo Jorge Millas 2011-2012, financiado por la Dirección de Investigación y Doctorados (VRID) de la Universidad Andrés Bello UNAB: «Ontología del cuerpo en la Filosofía de Jean Luc Nancy, Biopolítica, Alteridad y Estética de la Enfermedad». Áreas de Investigación: Biopolítica, cuerpo y filosofía de la mente, Alteridad, y ontología de la enfermedad. 


\begin{abstract}
There's no doubt that the iconographic potential of Nazi policy was an essential aspect of success over a people who quickly build their Führer as the center of your truth andthe support of his narcissistic image, with a high price to pay, of course. The paroxysmal realization of vanguardistic art, the hypnotic use of iconography that included not only the swastikas, but also the helmets of the Wehrmacht, some kind of boots, iron crosses, etc. realize a common handling practices in politics today, where priority is given to the mediatic fact at the expense of program content. Compared with the impact of the terrorist events of September 11, 2001, are two particular ways of analyzing the aesthetic reach of historical episodes that managed to completely break the barriers of the museum and take over the worldof life. Violence and death seem to be key factors in this particular form of avant-garde aesthetic.
\end{abstract}

Key words.- Avant-garde art, aesthetics Nazi, aesthetic terrorist, Adolf Hitler, September 11, Biopolitic

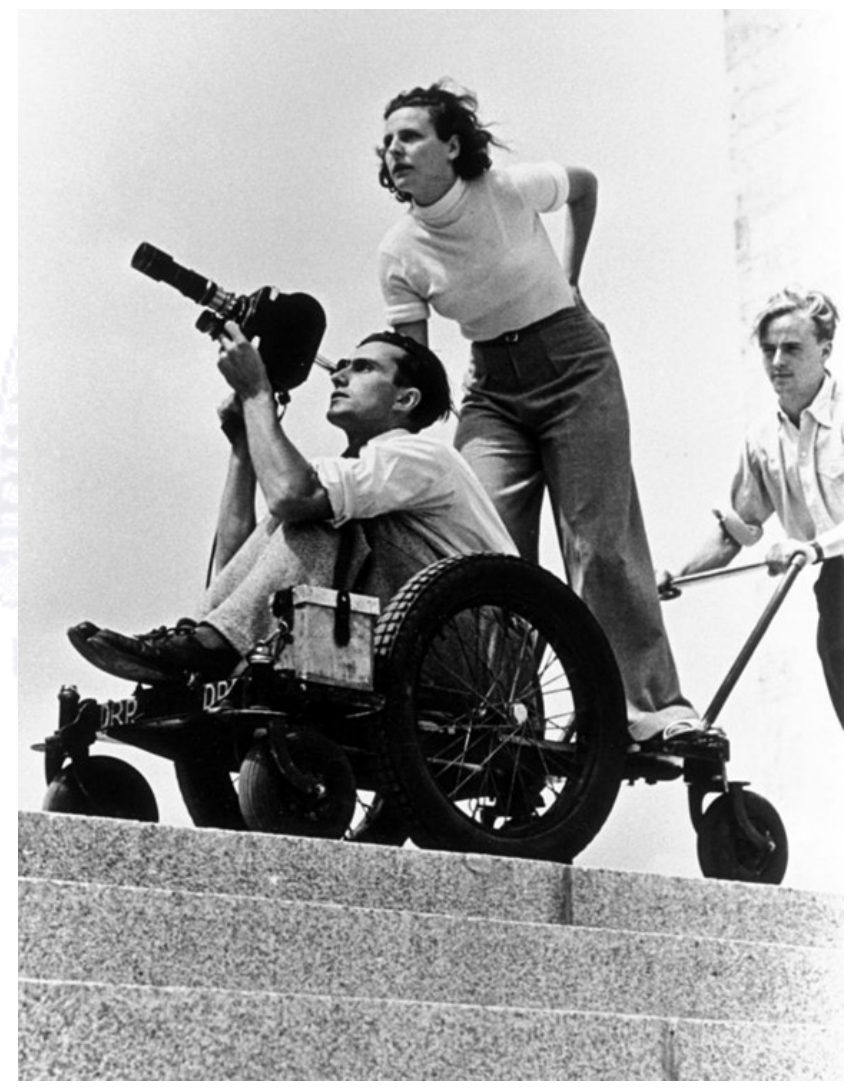

\title{
1.- La política como arte; 'belleza' convulsiva, y proyecto nacionalsocialista.
}

En todo esteticismo, en toda decoración, se esconde cierto cinismo y escepticismo, de ahí su carácter historicista y su maniaco revisionismo. El barroco de este realismo que olvida la realidad es precisamente neo-romántico y es este 'clima' el que da lugar al renacimiento de los nacionalismos. Los nacionalismos del siglo pasado resultan impensables sin la imagen ${ }^{2}$. Leni Riefenstahl ${ }^{3}$, la cineasta

El entreacto es la vanguardia y uno de los primeros elementos que debe considerar 
del nacionalsocialismo, lo entendió perfectamente. Ella se encargó de documentar esas "performances" que eran los desfiles militares y los mítines nazis. Registró en El poder de la voluntad a los grandes batallones nacionalsocialistas atravesando Berlín.

Hitler vivió el Kitsch sangriento de Nerón que estableció un artificio pirotécnico en Roma a cuenta de cuerpos humanos. Nada muy distinto al exterminio masivo de prisioneros en las cámaras de gas, donde muchos morían de asfixia por aplastamiento antes que se liberara el gas letal.

Pese al colapso del nazi-fascismo en 1945, los vínculos de Heidegger con momentos constitutivos genéricos del nazismo volvieron a revelarse continuamente. Así, por ejemplo, en Bremen, en los años 50, afirmaba que "La fabricación de cadáveres en las cámaras de gas y la transformación de la agricultura en industria alimenticia son en esencia lo mismo"4.

Lyotard confirma la adhesión de Heidegger al nazismo de manera deliberada, profunda y persistente: "Escuchamos este compromiso en los textos que firma, en los que pronuncia sin firmar, pero que se nos presentan con una plausibilidad convincente, los textos políticos pero también filosóficos (como el discurso del rectorado). Lo escuchamos en los silencios de esos textos, y en sus márgenes, y sobre todo [...] en el silencio sobre el exterminio, observado hasta el final". Lyotard refiere que la única frase escrita por Heidegger, en 1949, acerca del exterminio es la siguiente: "La agricultura es ahora una industria alimentaria motorizada, en cuanto a su esencia, lo mismo que la fabricación de cadáveres en las cámaras de gas y los campos de exterminio, lo mismo que la fabricación de bombas de hidrógeno", frase que Lyotard califica de absolutamente justa, porque sitúa

cualquiera que se acerque a ellas con serio afán de entenderla es su condición teatral. La vanguardia es teatralización como estado puro de nuestra afectividad.

3 Según Deleuze y Guattari el romanticismo alemán exonera al héroe-individuo de servir al pueblo y a las masas mediante el resguardo de la soledad, pero también se nos dice que "el fascismo utilizó mucho menos a Verdi que el nazismo a Wagner" (Mil Mesetas. Capitalismo y esquizofrenia. Valencia 1980, p.345). Lo sonoro (oído) prima sobre lo visual (vista) en materia de desterritorialización habiendo un "fascismo potencial de la música" (Deluze Op.cit. p.351): "Éxtasis o hipnosis. No se mueve a un pueblo con colores. Las banderas nada pueden sin las trompetas" (Ibid) de ahí que la cineasta nazi Leni Riefenstahl emplease ambas en su película El triunfo de la voluntad (1935). Se distingue aquí entre pueblo y masa, pero para nuestra sorpresa el nazismo y la música de Wagner son clasificados como fenómenos ligados al pueblo (y ciertamente estaban ligados a la mistificación del pueblo ario) y no como un fenómeno de masas. Pero en la obra de Riefenstahl lo que se percibe es un fascismo potencial del cine puesto en obra, un cine dispuesto para configurar la masa fascista en los términos en que había sido descrita por Freud en su Psicología de las masas y análisis del yo (1923), como un ser colectivo producido mediante la identificación, el enamoramiento y la hipnosis con relación a un Führer, líder y salvador. Yo distingo pueblo y masa de otra manera, pues para mí el pueblo en el buen sentido de la palabra, (no el ario ni el elegido), son las 110 millones de personas que se manifestaron consciente y simultáneamente en 60 países contra la guerra en Irak (febrero de 2003), mientras que las masas son los millones de borregos que pueblan en manadas los grandes centros comerciales. [precisamente el rasgo característico de la masa desde Le Bon y Freud es la pérdida de la individualidad y por tanto de la conciencia]

$4 \quad$ FARÍAS, Víctor; Heidegger et le Nazisme, Editions Verdier, Paris, 1987.

5 LYOTARD, J.-F. (1995) Heidegger y "los judíos". Buenos Aires: La Marca. 
Auschwitz en su verdadera escena: la técnica.

Nuestro tiempo es -en opinión de Jean-Luc Nancy ${ }^{6}$ - el tiempo en que la historia se suspendió a sí misma: donde advino la guerra total, el genocidio, la carrera de armamentos nucleares, la tecnología sin piedad, la hambruna y la miseria absoluta, todos estos signos 'apocalípticos' de la auto-destrucción del género humano.

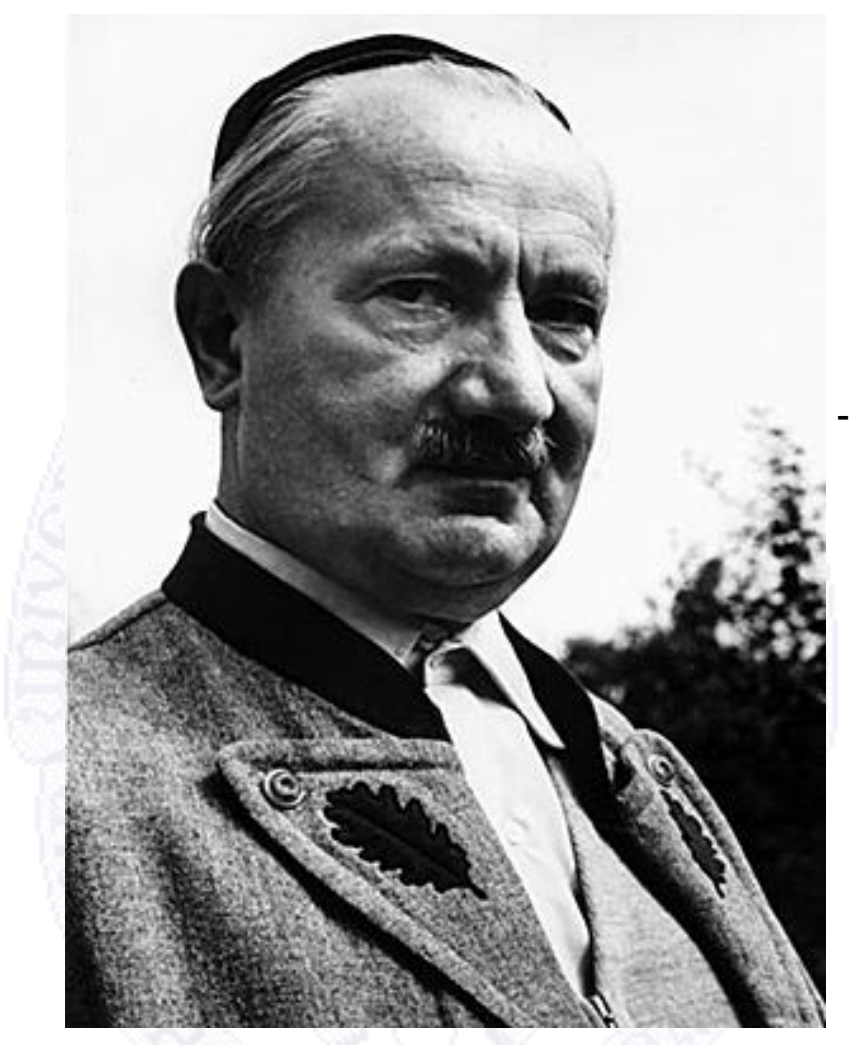

\section{2.- El artista como dictador social}

Tomemos un par de ideas, la del artista como dictador social o lo que parece su reverso, la del político como artista, pero no en el sentido clásico del arte de lo posible, sino en el sentido común del término. De este modo supongamos que nos estamos refiriendo al político como escenógrafo. Veamos qué obtenemos al aplicar este concepto a Hitler. Aquí, intentaré complementar ideas esbozadas en otros Artículos, y que hasta ahora han sido generalmente mal interpretadas; por ello aquí se requiere leer con atención y analizar con precaución las ideas que a continuación expondré. Una de ellas es el modo cómo los problemas estéticos están a la base de cambios ideológicos y sociales, así como la concepción de la política como obra de arte. Comencemos a diseñar el escenario para ilustrar la 
provocativa tesis acerca del valor cognoscitivo de la ficción, en particular de la historia novelada a partir de sobreinterpretaciones. Hitler posee una biografía bastante singular, generalmente ignorada. Desde muy pequeño sufrió los maltratos de su padre, llamado Alois Hitler el cual luego de varios matrimonios fallidos se caso con la que sería su madre Klara Polz, ella fue una de las dos mujeres que más amó en todo el mundo y a la que acompañó hasta el día de su muerte, de hecho se dice que él mantuvo durante toda su vida un retrato de su madre al lado de su cama. Desde muy pequeño, alrededor de los 17, se postuló a su única vocación que era la pintura pero su solicitud fue rechazada por la academia de bellas artes, sin darse por vencido, vuelve a intentarlo el año siguiente cosechando los mismos resultados. A los 47 años su madre muere de cáncer y queda completamente solo, ya que su padre había muerto un par de años antes. Por ser menor de edad, le correspondía un cupo en la pensión de huérfanos la cual cedió a su hermana Paula, que fue su única hermana por ambos lados. Luego de esto se dedico a vagar por las calles de Viena y vivía gracias a algunos dibujos que lograba vender. Como comentaban algunos de los más cercanos al joven Hitler, nunca pudo cuajar una amistad de verdad y ni siquiera tenía relaciones con el sexo opuesto. Nunca tuvo interés por inscribirse al servicio militar de Alemania ya que era visto como débil, pero viéndolo como única alternativa se postuló siendo rechazado por tener un físico inadecuado para portar armas. Al estallar la primera guerra mundial decide inscribirse como voluntario, quedando en dos ocasiones gravemente herido. Llegó tiempo después a considerarse, en un sueño megalómano, como el elegido para conducir el destino de Alemania; de esta manera, gradualmente, logra subir de nivel en los puestos de su país, no fueron cargos que tomó él mismo por la fuerza, si no que fueron correctamente obtenidos por votaciones electorales. Hecho poco atendido por la historia. La gran pregunta es cómo un hombre que desde pequeño no destacaba en ningún ámbito, un hombre más bien vulgar y corriente, pudo alcanzar tal nivel de poder como el que obtuvo y cómo pudo lograr que una nación entera, tan culta como la alemana, le rindiera pleitesías y lo viese como el gran líder que volvería a Alemania a su época de máximo esplendor, "el Tercer Reich duraría mil años" eran sus palabras-. Es claro que la coyuntura económica de Alemania no explica por sí sola el éxito de Hitler. Ahora bien, aquí comenzamos a poner en juego una de nuestras interpretaciones o sobreinterpretaciones: Hitler, según confesión propia, nunca dejo de pensar en sí mismo como un artista que sacrificó el ejercicio de su talento estético en aras del deber. Aún cuando se podría decir, bajo ciertos términos, que no lo sacrificó, simplemente lo lanzó a una dimensión hasta ahora incomprendida por la historiografía. Para leer el mundo y sus sucesos sospechosamente -y establecer sobreinterpretaciones- es necesario haber elaborado algún tipo de método obsesivo. La sospecha, en sí misma, no es patológica: tanto el detective, el científico, como el historiador sospechan en principio que algunos elementos, evidentes pero en apariencia insignificantes, pueden ser indicio de otra cosa que no es evidente $y$, sobre esta base, elaboran una nueva hipótesis que hay que fundamentar. Sin embargo, se considera que el indicio es signo de otra cosa sólo cuando cumple tres condiciones: que no pueda explicarse de forma más económica; que apunte a una clase limitada de causas posibles y no a un número indeterminado de causas diversas; y que encaje con 
los demás indicios, porque, ¿qué son sus experimentos médicos con presos, las mutilaciones, los ensayos de metamorfosis o el exterminio masivo de reclusos en las cámara de gas, donde muchos morían de asfixia por aplastamiento antes que se liberara el gas letal? Tampoco podemos olvidar esas "performances" que eran los desfiles militares y los mítines. Sin duda alguna las manifestaciones dadaístas, surrealistas y situacionistas, comparadas con la "poesía" hitleriana, fueron un "simple arrebato neorromántico". La mayoría de historiadores, artistas e intelectuales, cierran los ojos ante la evidencia histórica. Esto -que- haría enfurecer a André Bretón, sin embargo -que duda cabe- es una paradójica verdad; aquí el papa del surrealismo es engañado por su propio truco. André Bretón cae en todo tipo de contradicciones. André Bretón, el hombre que sólo aceptaba como arte el libre fluir del inconsciente sin ningún tipo de censura estética, moral o lógica; el hombre que había proclamado que el acto surrealista por excelencia era bajar a la calle empuñando un revólver y disparar al azar contra la muchedumbre, este mismo hombre, expulsa a Dalí del surrealismo por pintar "El enigma de Hitler", y se escandaliza cuando otro miembro del grupo surrealista, sin ningún tipo de motivación, quema la puerta de su casa, con grave riesgo de provocar una gran catástrofe. Tampoco pueden leerse las memorias de Luis Buñuel $^{7}$ sin sentir un poco de vergüenza por su idiotez ejemplar. En ellas nos cuenta como la gente vio lirismo y poesía (se refiere a la película "Un chien andalou") donde sólo había una vehemente apología del asesinato. Más allá de las ironías supuestas, debemos reconocer que sí bien los dadaístas fueron los primeros, los originales, los creadores de la expresión más pura y violenta del arte del siglo XX, es también necesario reconocer que Adolf Hitler fue el dadaísta más colosal, el más espectacular y, como no, el más siniestro y macabro. Fue precursor del body-art, de la performances, de los happenings thanaticos. Un situacionista aventajado, para el cual la vida diaria era una locura desatada; un payaso para el que sólo existía una única realidad y, por tanto, todo debía tomarse en serio: ejemplo proteico de un sintético, indivisible, que no observó jamás que pudiera haber diferencia alguna entre la vida, la política y el arte. ¿Cómo un asesino en masa pudo ser quien anticipará estas ideas que están a la base de la posición de cierta vanguardia nihilista?

7 BUÑUEL, Luis. Mi Último Suspiro, Editorial: Plaza \& Janes Editores, Barcelona, 1983. 


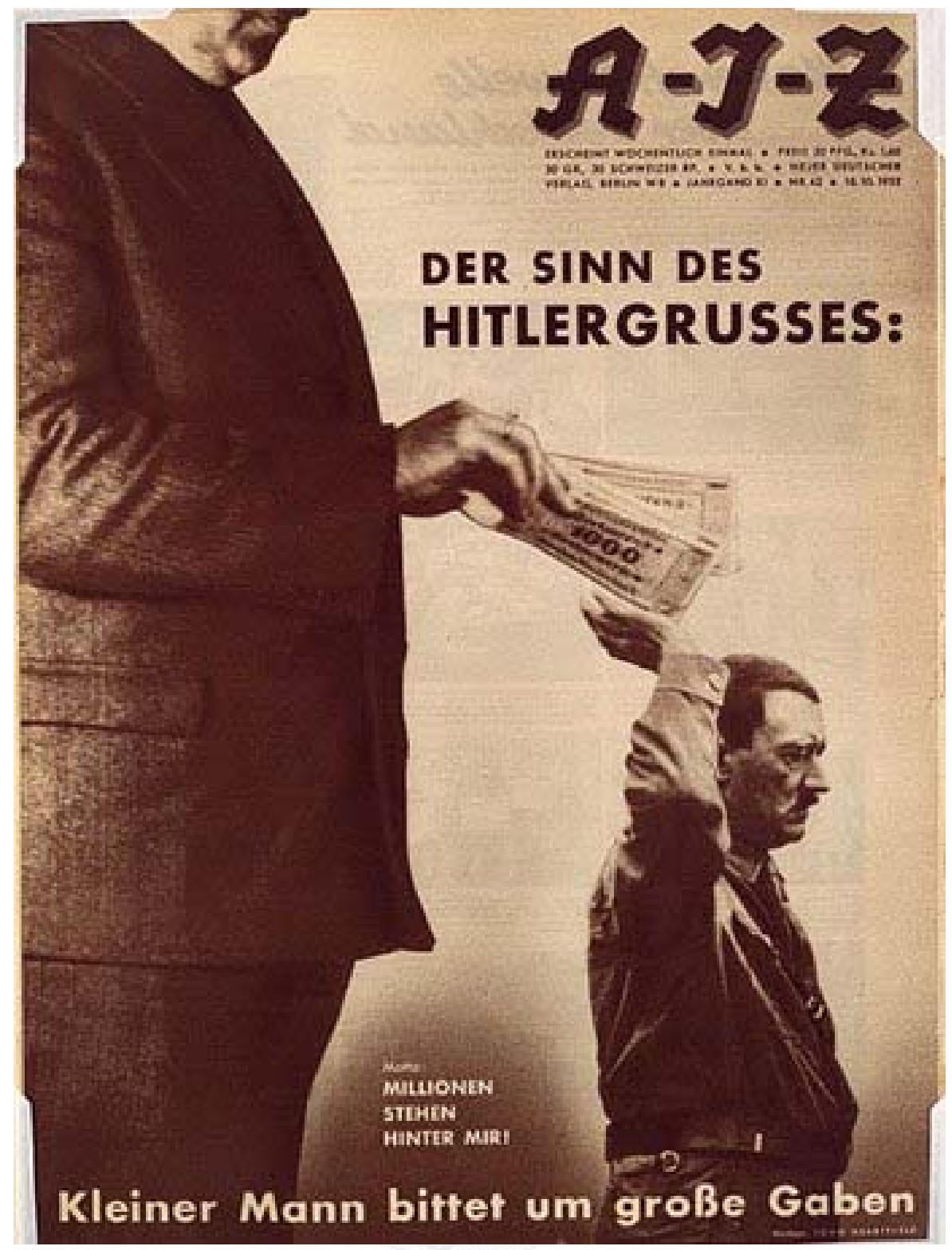

\section{3.- El político como escenógrafo.}

Hitler, que tenía veleidades de pintor y arquitecto, abordó la política siempre con referencia a imágenes, sus planes, pese a su mediocridad como artista, siempre tuvieron una dimensión estética e iconográfica. En esto fue muy sistemático. Puede decirse que su política era insustancial en términos de contenidos programáticos, pero era particularmente densa en la convocatoria mediante las imágenes. El ingrediente visual y artístico de su política fue un aspecto esencial de su éxito. Su política no apelaba a la razón, a la capacidad de entendimiento, sino a la emoción y a la fantasía, cosa que se hace mucho mejor con imágenes o efectos 
oratorios que con discursos sustanciosos. El corazón y la sensibilidad de las masas eran su objetivo. Y lo lograba porque se comunicaba con el alemán medio apelando a las imágenes y símbolos nacionales: los bosques brumosos, las aldeas campesinas, las valquirias ecuestres, que habían sido impuestos por un siglo de propaganda nacionalista. En este sentido es que su política era profundamente antiliberal: despreciaba y procuraba sumir al individuo en la comunidad. Lo importante era la unidad y la fuerza de la nación nos las opiniones o la libertad de cada individuo. La política de Hitler era, en definitiva, como la música de Richard Wagner, desmesuradamente emotiva, dominada por climas sugestivos para el oyente más que por ideas musicales originales o sustanciosas. Sus discursos no delineaban un programa ni hacían promesas, reclamaban un compromiso. Para él la política era un juego de movilización de voluntades, lo que suponía anular las individualidades. El oyente le rendía su voluntad a él, el líder, que se la devolvía fortalecida. Como él mismo lo explicó: "El hombre que se incorpora a ese mitin dudando y vaciándolo, lo abandona reforzado: se ha convertido en un eslabón de la comunidad". En el capitulo sexto de su libro Mi lucha ${ }^{8}$, Hitler escribió que el propósito de toda propaganda es "presionar y limitar el libre albedrío del hombre". Y para ello apeló a una meticulosa escenografía en sus actos políticos. Fue el primer político que apreció el real poder de la amplificación y el efecto emocional de los focos, lo que aplicó de forma sistemática en sus masivos mítines nocturnos. Ahora bien, no tiene nada de disparatado la comparación entre los públicos de rock and roll y los actos de masas de los nazis. Cualquier cosa que pueda congregar a ese número de personas es política -diría William Burroughs-. Por otra parte, en su carácter de estrella de esas óperas políticas que eran sus actos, ensayaba hasta el detalle. Siempre estudiaba la acústica de las salas donde hablaba, practicaba frente a un espejo y encargaba a un fotógrafo del partido que lo tomara en todos los detalles para luego poder estudiar las tomas. La estética wagneriana de la política sirvió a Hitler para seducir a los alemanes, el pueblo más instruido de Europa en ese tiempo. Al respecto es también relevante el testimonio de Feyerabend ${ }^{9}$, testigo de época. Según su descripción, los actos de Hitler -en su ascenso al poder- seguidos por muchos austriacos, poseían una coreografía perfecta. "Bandas militares tocaban melodías conocidas. Paraban, comenzaban, paraban, volvían a empezar: Hitler nunca fue puntual, De pronto, la Badenweilermarsh, la marcha preferida de Hitler. Un griterío entusiasta se escuchaba a lo lejos, se acercaba, subía de volumen hasta que toda la audiencia era una masa rugiente de júbilo. Uno o dos discursos de Goebbels, Hess, Goering o alguno de los dirigentes nazis locales y, finalmente, Hitler. Comenzaba lentamente, titubeante, con voz baja y sonora: "Volksgenossen und Volksgenossinnen" (Compatriotas, hombre y mujeres). Muchas personas, jóvenes y viejas, hombres y mujeres, mi madre entre ellas, eran hipnotizados por su voz. Bastaba con oírle para que se sintieran paralizadas. "Amaba a Hitler", escribe Ingmar Bergman en su autobiografía ${ }^{10}$, contando sus impresiones de estudiante adolescente en intercambio. "El único rostro entre hombres sin rostro", fue la

HITLER, Adolf, Mi Lucha, Ediciones Wotan, Barcelona, 1995 FEYERABEND, Paul, Matando el Tiempo, Autobiografía, Editorial Debate, Madrid. 1995. BERGMAN, Ingmar, Linterna mágica. Editorial Tusquets, Barcelona, 1988. 
reacción de Heidegger. "Es un fenómeno: qué lástima que yo sea judío y él antisemita", dijo Joseph von Sternberg, el descubridor de Marlene Dietrich, director de El ángel azul y de muchas películas de Hollywood después. Hitler aludía a los problemas y los logros locales; hacía chistes, algunos de ellos bastante buenos. Gradualmente cambiaba el tono del discurso; al abordar los obstáculos y los reveses, Hitler aumentaba la velocidad y el volumen. Los estallidos que eran las únicas partes de sus discursos que el mundo conocía estaban cuidadosamente preparados, bien escenificados y aprovechados en un tono más calmado cuando habían pasado. Eran resultado del control, no de la cólera, el odio o la desesperación, al menos mientras Hitler estuvo en una buena forma física y al frente de los acontecimientos.

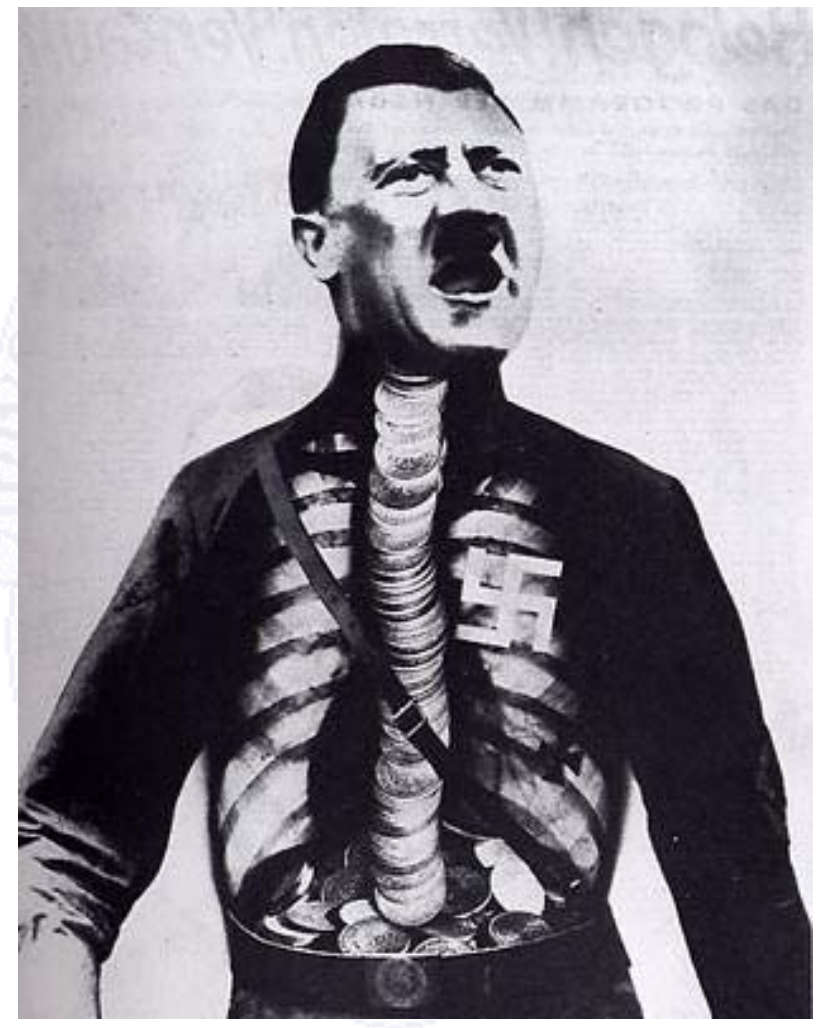

Sin duda el potencial iconográfico de la política nazi fue un aspecto esencial del éxito sobre un pueblo que no tardó en erigir a su Führer como el centro de su verdad y el sostén narcisístico de su imagen, con un precio muy alto a pagar, por supuesto. La realización paroxística de acciones de arte vanguardista, la hipnótica utilización de una iconografía que incluía no sólo las esvásticas; también los cascos de la Wehrmacht, cierta clase de botas, las cruces de hierro, etc. dan cuenta de una de las prácticas de manipulación habituales en la política de hoy, donde se prioriza lo mediático en desmedro del contenido programático. 
Como se ve el potencial iconográfico de la propaganda nazi reemplazó la sustancia de los que carecían sus programas políticos. La importancia que Hitler atribuía a la manipulación de las masas y la movilización de las voluntades a través de las imágenes y presentaciones públicas en las que destacaban sus capacidades histriónicas y operísticas. De allí que Woody Allen dijera: "escucho música de Wagner y me dan ganas de invadir Polonia"11 Estas prácticas se han hecho hoy habituales en la política, en la importancia que cobran los debates televisivos con su despliegue retórico y gestual donde impera la impresión sobre la audiencia, donde se prioriza lo mediático en desmedro del contenido programático.

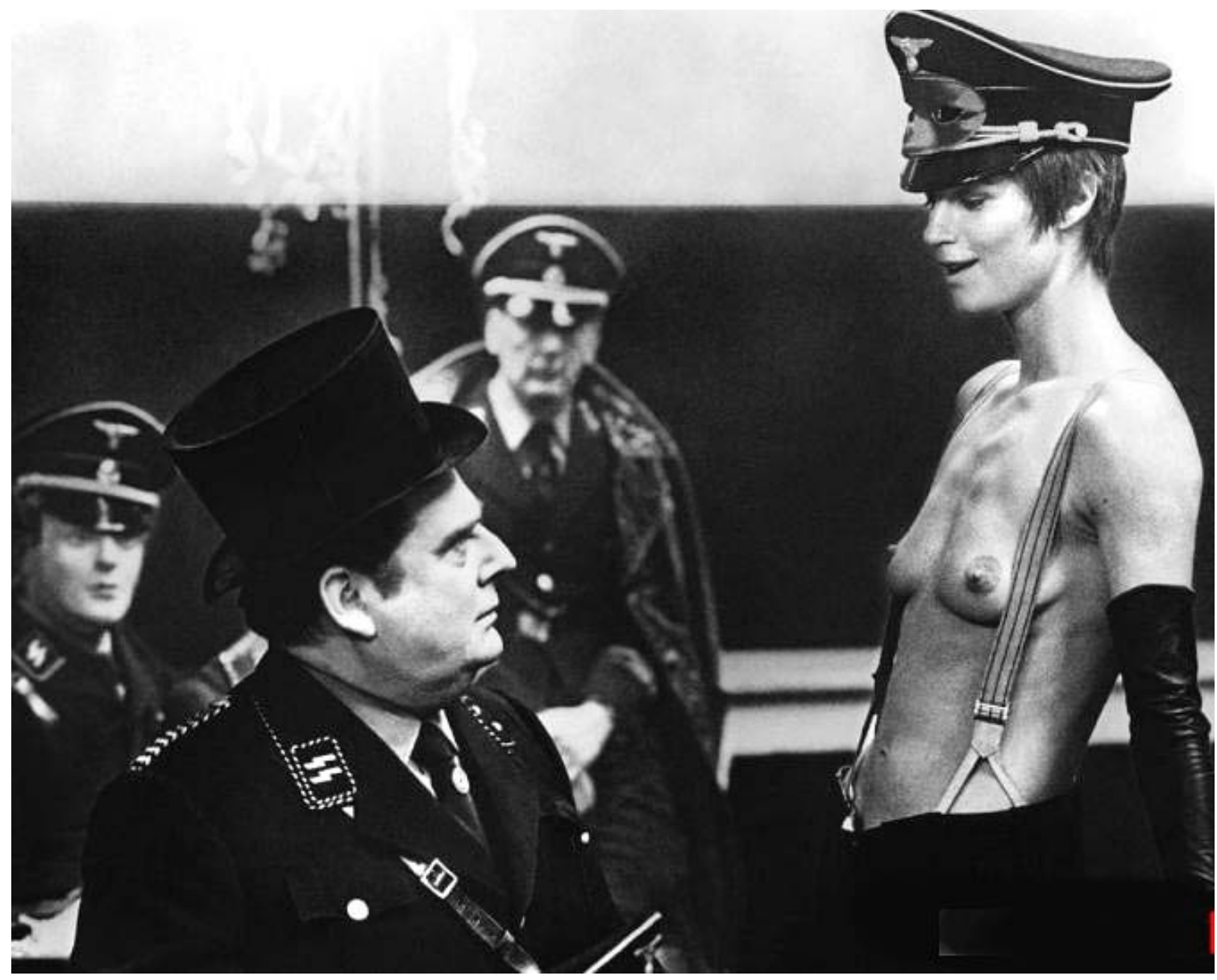

Recogiendo el testigo de una tradición que se remonta hasta el incendiario Nerón y sus megalómanos delirios destructivos Hitler devolverá al arte el sustrato épico y total que acabará dinamizando toda su obra -sí, es ese mismo "teatro total" con el que Artaud había soñado- y fundirá, ya para siempre, vida y representación: realidad y ficción. Hitler, como sabemos, nunca dejó de pensar en sí mismo como una especie de artista que sacrificó el ejercicio de su talento estético en aras del deber. Nosotros hoy, podemos decir que se equivocaba: las acuarelas de sus 
primeras actividades creativas han sido sustituidas por campos de concentración y su violencia voraz.

\section{4.- Hitler y las masas; Los asesinos están entre nosotros.}

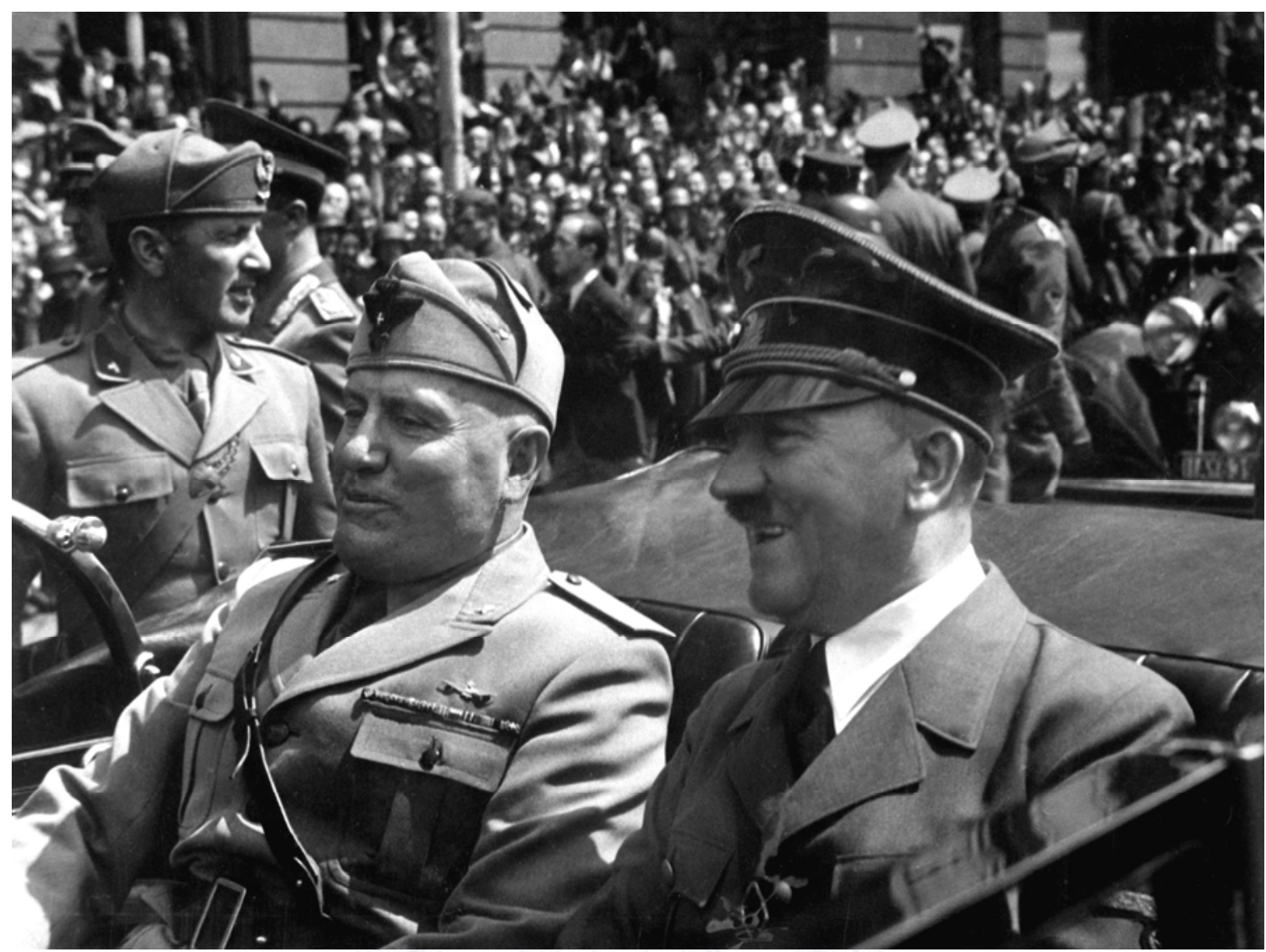

El nacionalsocialismo se apropió de los tesoros de la Cultura alemana. Utilizaron a Goethe, Schiller, Beethoven o a Fichte, lo propio intentaron con Nietzsche, aunque a apropiación de Nietzsche por parte de ideólogos del nacionalsocialismo como Alfred Baeumler estaría destinada al fracaso: Semejante apropiación no dejaba de discutirse precisamente entre los ideólogos fuertes del nazismo. Ernst Krieck, por ejemplo, previene sarcásticamente frente a una adaptación de Nietzsche: "En resumen, Nietzsche era enemigo del socialismo, y lo era también del nacionalismo y del pensamiento racial. Si se prescinde de estas tres direcciones intelectuales, quizás habría podido salir de él un nazi destacado"12. Los ideólogos del nacionalsocialismo intentaron apropiarse también de la idea de vivir en 'armonía' con la naturaleza, esto a partir de la mistificación de la tierra y el suelo alemán. Los ideólogos del Partido Nacionalsocialista Alemán de los Trabajadores (NSDAP)

12 SAFRANSKI, Rüdiger (1994), Un Maestro de Alemania; Martin Heidegger y su tiempo, Editorial Tusquets, Barcelona, p. 2007, p. 350 
de Hitler, entre ellos -el leal Ministro de Propaganda del Führer- Joseph Goebbels, se dieron sin embargo cuenta de que el Romanticismo tradicional era demasiado blando. Por ello quisieron alcanzar un nuevo romanticismo al que llamaron "Romanticismo de acero". Un Romanticismo militarista y heroico que poco tenía que ver con el original. La auténtica ideología de los nazis fue el "biologismo" [la intervención de la mano humana en los procesos biológicos], el darwinismo social y el racismo. Especialmente se trató de una perversión pseudocientífica de la naturaleza que arraigó en la segunda mitad del siglo XIX, sin relación alguna con el Romanticismo tradicional. Pese a ello la actitud romántica llevó en la Cultura alemana a una sensación de extrañeza respecto al mundo y a un desdén hacia lo político. La consecuencia es que los peligros del movimiento nazi no fueron detectados. La cultura política de la elite en el poder se debilitó. Tampoco podemos olvidar que el movimiento posterior contra Hitler, sobre todo el atentado del coronel Claus von Stauffenberg (20 de julio de 1944) también tuvo una inspiración "romántica". La "Alemania mejor" por la que actuaban no dejaba de ser la Alemania romántica ${ }^{13}$.

Ahora bien, a la hora de intentar explicar el fenómeno cruento que constituye el nazismo, el auge y desarrollo del Tercer Reich, con su maquinaria de exterminio, gran parte de los historiadores ignoran o minimizan el factor psicológico que está a la base de estos fenómenos de masas. Ello queda demostrado por las notables lagunas que se dejan entrever en el conocimiento de la historia alemana, desde la primera guerra mundial hasta el triunfo final de Hitler $^{14}$.
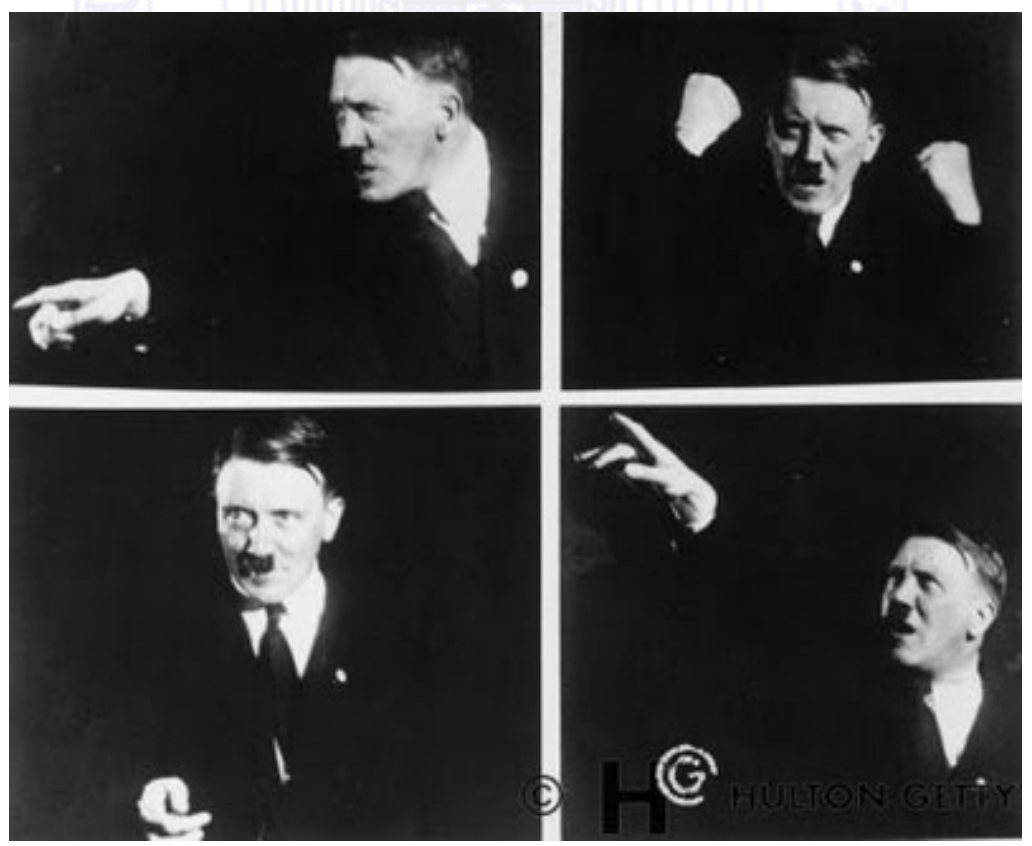

\footnotetext{
13 SAFRANSKI, Rüdiger, "Los movimientos antisistema son los herederos del espíritu del romanticismo", En El CULTURAL - Revista de cultura de EL MUNDO, Editado por Prensa Europea del Siglo XXI, S.L., Publicado el 19/06/2009.

14 KRACAUER, Siegfried, De Caligari a Hitler. Una historia psicológica del cine alemán, Paidós, Barcelona, 1995., p.18
} 
Aunque ello es así, esos factores políticos, sociales y económicos no bastan para explicar el profundo impacto de Hitler en la población alemana. De manera significativa, muchos observadores alemanes se negaron hasta el último momento a tomar a Hitler en serio, y aun después de su advenimiento al poder juzgaron al nuevo régimen como una aventura transitoria. Tales opiniones indican, por lo menos, que en la situación interior existía algo inexplicable, algo que no podía inferirse de las circunstancias comprendidas dentro del campo normal de visión.

Esta fuerte oposición ideológica que resistía a Hitler tiende a sugerir que fue un puñado de fanáticos y gángsters el que logró sojuzgar a la mayoría del pueblo alemán. Esta conclusión no se ajusta a los hechos. En lugar de resultar inmune al adoctrinamiento nazi, la mayoría de lo alemanes se plegó al gobierno totalitario con tal presteza que no podía ser un simple resultado de la propaganda, mientras el fascismo italiano era una especie de representación teatral, el nazismo asumió aspectos de religión ${ }^{15}$.

Era un espectáculo desconcertante: por un lado los alemanes se resistían a darle las riendas a Hitler y por el otro estaban completamente de acuerdo en aceptarlo. Tales actitudes contradictorias surgen frecuentemente de conflictos entre las demandas de la razón y las urgencias emocionales. Puesto que los alemanes se oponían a Hitler en el plano político, su extraña predisposición por el credo nazi debe haberse originado en disposiciones psicológicas más potentes que cualquier escrúpulo ideológico.

El fascismo es un fenómeno absolutamente develador. Muy raras veces nos ha ofrecido la larga y tortuosa historia de la naturaleza de los partidos modernos un ejemplo tan significativo de las necesidades interiores de la masa respecto a su 'culto al héroe' como la ofrecida por el fascismo y el nazismo. Una confianza absoluta, ciega y una ardiente veneración, he aquí lo que ofrece este partido a su Führer, a su Duce.

Esto, el fenómeno del 'culto al héroe', pone de manifiesto que en las oscuras turbas humanas existe un aspecto que no cesa de soñar en una luminosidad más grande. En la práctica, las masas desarrollan su propia forma de idealismo e imponen de vez en cuando su voluntad de ensalzamiento del héroe sin hacerla objeto de discusión.

Pero ningún culto a la persona resulta más ilustrativo de la idealización horizontal que aquel del que fue objeto Hitler. Este fenómeno, en lo esencial, nunca fue otra cosa que la autoidolatría de una ávida mediocridad apoyada por la figura del Führer como medio de culto público. También el culto a la persona constituye una fase del programa para desarrollar la masa como sujeto. De ahí que, a la vista del fenómeno de la generalización constante de la comunicación en los Estados nacionales, sea lícito comprender a los héroes de la época burguesa y de masas, sean dictadores clásicos o populares, como testimonios de que los individuos también podían intervenir en calidad de medios de masas. Por esta razón, el culto

15 KRACAUER, Siegfried, De Caligari a Hitler. Una historia psicológica del cine alemán, Paidós, Barcelona, 1995., p.192 
al genio y el culto al Führer pudieron intercambiar de manera intermitente su forma sin complicaciones. Con todo, tuvo que actuar el peculiar talento alemán para la autohipnosis para escenificar esa luna de miel entre idealismo y brutalidad que originó, en los embriagadores albores de la "Revolución Nacional" de 1933, ese clima de ilusión tan especial para las masas. Fue Thomas Mann quien supo expresar esta situación en términos de minoría de edad cuando él, en septiembre de 1939, ya dispuesto a emigrar a los Estados Unidos, realizó el diagnóstico de que los alemanes eran un pueblo que idolatraba la falta de formación y la barbarie". Esta idolatría, no obstante, no era más que una forma de desvío del deseo de reconocimiento. Todo aquel que desde la distancia histórica pretenda comprender el efecto producido por Hitler, señala Sloterdijk ${ }^{16}$ tiene que renunciar al intento de investigar al dictador como una figura dotada de una personalidad demoníaca.

La específica adecuación del papel desempeñado por Hitler en el psicodrama alemán no estriba en sus extraordinarias aptitudes o en su reconocido carisma, sino, antes bien, en su incomprensible y evidente vulgaridad, por no hablar de su consecuente disposición a vociferar sin rebozo alguno delante de grandes multitudes. Hitler parecía llevar de nuevo a los suyos a una época en la que gritar todavía servía para algo. Desde este punto de vista, fue el artista de la acción más exitoso del siglo ,un exitoso artista de la acción y de la puesta en escena de masivas liturgias hipnóticas.

El relato de Sloterdijk describe el desenfreno y la violencia política a flor de piel en la luna de miel entre el idealismo y la brutalidad. Hannah Arendt pone el final: un salto mortal al primitivismo. Individuos impotentes y desorganizados que se dejan dominar y alcanzan un desamparo organizado: esos son los que perciben a la figura humana bajo el sello de la insignificancia cósmica, como lo señalara Niklas Luhmann.

Es en este plano horizontal de resonancia ya apuntado donde se asienta la continuidad funcional existente entre el culto al líder de las masas encaminadas a la descarga durante la primera mitad de nuestro siglo y el culto al estrellato de las masas ansiosas de entretenimiento que surge en su segunda mitad. El misterio que envuelve tanto al antiguo líder como a las estrellas de nuestra actualidad reside precisamente en el hecho de ser tan similares entre sí ante sus embotados admiradores, tanto que alguien involucrado apenas podría llegar a barruntarlo. Aunque también los mismos eminentes intelectuales alemanes llegaran a participar en este salto mortal al primitivismo", esta situación en absoluto desacredita la mencionada conexión; pone de manifiesto, más bien, la superficie de contacto que permitió la "alianza entre vulgo y elite". Es en este terreno donde, según el diagnóstico de Hannah Arendt $^{17}$, la impotencia desorganizada de innumerables individuos se trueca en el "desamparo organizado" de una mayoría que se deja dominar tanto por los movimientos totalitarios como por los medios de entretenimiento totales.

16 SLOTERDIJK, Peter, El desprecio de las masas. Ensayos sobre las luchas culturales de la sociedad moderna, Pre-textos, Valencia, 2001, p. 25

17 ARENDT, Hannah, Los orígenes del totalitarismo. Alianza Universidad, 1987. 
En lo que concierne a las aptitudes de Adolf Hitler, el diagnóstico es claro. Mientras cumplió sus labores como Führer, no actuó en absoluto como la ensalzada contrafigura de una masa guiada por él mismo, sino como su delegado y catalizador. En todo momento adoptó el mandato imperativo de la vulgaridad. No alcanzó el poder gracias a algún tipo de aptitud excepcional, sino merced a su inequívoca grosería y a su manifiesta trivialidad. Si algo había de especial en él, residía tan sólo en el hecho de que parecía haber inventado su vulgaridad en todo su ser, como si fuera el primero en reconocer en esa misma vulgaridad una meta que podía ser perseguida hasta sus últimas consecuencias. La autoconciencia de Hitler de ser la encarnación de un destino se adecuaba en este sentido a su papel de instrumento histórico. En él, el narcisismo vulgar fue capaz de entrar en escena. Para muchos, en él, y a través suyo, el sueño de una gran eclosión, libre de esfuerzos, podía cobrar visos de realidad. Dado que él estaba en condiciones de anular las ilusas infamias de los grupos más diferentes, pudo actuar desde diferentes lugares como una suerte de imán. Sólo como médium polivulgar fue capaz de crear el denominador común de sus partículas afines a su adhesión. El hermano Hitler tendió su mano a todos los que querían consumar su destino por su cuenta. Quien estaba dispuesto a eliminar toda percepción de la realidad para así poder fantasear mejor acerca de un salvador -incluso acerca de ese "redentor cultural" anunciado por los georgianos-, podía esta máscara comprometerse con todo lo que quisiera. Sin embargo, aun cuando las masas no fueran capaces de reconocer por sí mismas que tenían ante sí a una marioneta perversa, un niño mimado, coprófilo e impotente de tendencias suicidas explícitas, fueron los rasgos histéricos, megalómano-populistas e histriónicos de su carácter los que se evidenciaron desde el comienzo de manera más notoria e inmediata. De ahí que todavía hoy digan más de su figura los documentos gráficos que las miles de biografías al uso. Entonces se le ve siempre posando para las ilusiones de la masa: pero allí donde cae la pose, sólo queda el hueco del colérico médium falto de carácter. Hitler, el recolector de ilusiones y el político hipnótico, no era en absoluto un hombre de excesivo talento, como tampoco era en ningún aspecto una personalidad creativa. Para que tuviera éxito, sólo bastaba que fuera capaz de ser un receptor -catalizador- popular.

Reflexionando sobre la adhesión que recibió Hitler en el marco de la sociedad de masas no pretendemos indagar si hubo o no una amplia mayoría que siguió la política antisemita de Hitler, sino considerar como llegó al poder, esto es por la vía democrática; que tuvo seguidores fanatizados y seguidores que sólo fueron parte semi-inconsciente de la máquina genocida, esto es en su carácter de masa; que así como tuvo adeptos tuvo también adversarios, quienes a pesar que trataron, no lograron destronar rápidamente esa política por no contar con aquella hegemonía masiva con la que sí contaba el régimen.

Una figura histórica que haya provocado tanto daño debe ser estudiada en profundidad. Aunque hay una marea de libros y monografías en torno a Hitler muy pocos son los que han analizado la zona oscura, las raíces del mal. La historiografía oficial utiliza la técnica del avestruz. Aquello que escapa a su comprensión lo rechaza como imposible. Aunque tal rechazo implique aceptar que al final la Guerra Mundial se debió a la mala suerte de que llegase un loco al poder 
de Alemania. Esta actitud es un insulto a la inteligencia. ¿Quién fue realmente Hitler? ¿Cómo explicar que uno de los pueblos más cultos de la época se dejara embaucar por un loco? ¿Cómo pudo un tipo con un bigotillo ridículo pasar de vagabundo a intentar, y casi conseguir, la conquista del mundo? ¿Qué eran esos símbolos extraños de que se rodeaba?

Resulta al menos curioso que el país más culto de Europa tras la derrota y humillación de 1918 volvió su mirada hacia un pasado mítico y legendario de grandeza donde encontrar consuelo. El paganismo que no había desaparecido por completo de Europa regresaba de la mano de los círculos iniciados y ocultistas. Thor, Wotan y otros dioses extraños regresaban a sus dominios precristianos.

El nazismo hunde sus raíces en el río ocultista que recorre Europa desde el siglo XVIII. Organizaciones secretas como la Deutscher Bund, la Tugembud, los lluminados de Baviera o Thule, fueron sin lugar a dudas materia de inspiración para el nazismo. Debemos recordar aquellas palabras de Hitler cuando afirmaba que «aquel que vea en el nazismo un movimiento político, es que no ha entendido nada». La gran fuerza del nazismo se encuentra en ser fundamentalmente un movimiento espiritual e irracional, donde prima la intuición sobre la razón, la acción sobre la contemplación. La fuerza del mito cobra en el nazismo un protagonismo absoluto.

En la actualidad junto a la irrupción de neonazis que exhiben viejas insignias, nueva extrema derecha recorre Europa que ha entendido que su supervivencia exige un "lavado" de imagen: viste informalmente y niega ser racista -al tiempo que niega el holocausto- y declara un compromiso con la democracia. Por lo tanto, recordar el pasado puede lograr que ese odio se reprima y no se convierta en fuerza hegemónica bajo un disfraz o sensorium nuevo. 
Adolfo Vásquez Rocca PH. D.

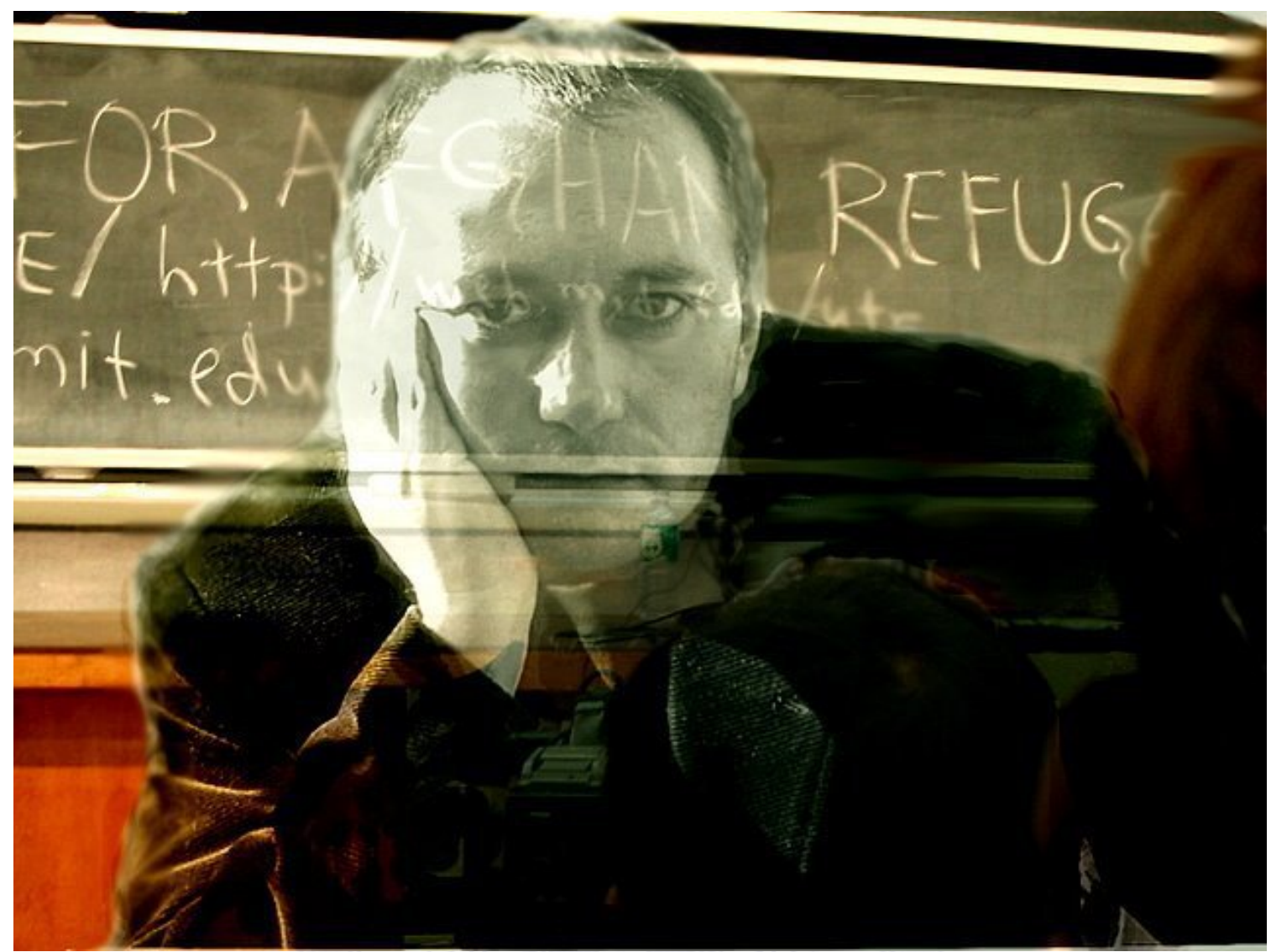

**Doctor en Filosofía por la Pontificia Universidad Católica de Valparaíso; Postgrado Universidad Complutense de Madrid, Departamento de Filosofía IV. Profesor de Postgrado del Instituto de Filosofía de la Pontificia Universidad Católica de Valparaíso; Profesor de Antropología y Estética en el Departamento de Artes y Humanidades de la Universidad Andrés Bello UNAB. Profesor de la Escuela de Periodismo y Arquitectura UNAB Santiago. - En octubre de 2006 y 2007 es invitado por la 'Fundación Hombre y Mundo' y la UNAM a dictar un Ciclo de Conferencias en México. - Miembro del Consejo Editorial Internacional de la 'Fundación Ética Mundial' de México. Director del Consejo Consultivo Internacional de 'Konvergencias', Revista de Filosofía y Culturas en Diálogo, Argentina. Miembro del Conselho Editorial da Humanidades em Revista, Universidade Regional do Noroeste do Estado do Rio Grande do Sul, Brasil y del Cuerpo Editorial de Sophia -Revista de Filosofía de la Pontificia Universidad Católica del Ecuador- . Director de Revista Observaciones Filosóficas. Profesor visitante en la Maestría en Filosofía de la Benemérita Universidad Autónoma de Puebla. - Profesor visitante Florida Christian University USA y Profesor Asociado al Grupo Theoria -Proyecto europeo de Investigaciones de Postgrado- UCM. Académico Investigador de la Vicerrectoría de Investigación y Postgrado, Universidad Andrés Bello. Artista conceptual. Ha publicado el Libro: Peter Sloterdijk; Esferas, helada cósmica y 
políticas de climatización, Colección Novatores, $N^{\circ} 28$, Editorial de la Institución Alfons el Magnànim (IAM), Valencia, España, 2008. Invitado especial a la International Conference de la Trienal de Arquitectura de Lisboa | Lisbon Architecture Triennale 2011

\section{BIBLIOGRAFÍA:}

- ARENDT, Hannah, Los orígenes del totalitarismo. Alianza Universidad, 1987.

- $\quad$ LYOTARD, J.-F., Heidegger y “los judíos”. Buenos Aires: La Marca, 1995.

- $\quad$ ALLEN, Woody, Sin plumas. Barcelona. Tusquets Editor. 1976 (1ª edición)

- BUÑUEL, Luis. Mi Último Suspiro, Editorial: Plaza \& Janes Editores, Barcelona, 1983.

- $\quad$ BERGMAN, Ingmar, Linterna mágica. Editorial Tusquets, Barcelona, 1988.

- $\quad$ FARÍAS, Víctor; Heidegger et le Nazisme, Editions Verdier, Paris, 1987.

- FEYERABEND, Paul, Matando el Tiempo, Autobiografía, Editorial Debate, Madrid. 1995.

- HEIDEGGER, Martin, Ser y Tiempo, Trad. Jorge Eduardo Rivera, Editorial Trotta. Madrid, 2003.

- $\quad$ HITLER, Adolf, Mi Lucha, Ediciones Wotan, Barcelona, 1995.

- KRACAUER, Siegfried, De Caligari a Hitler. Una historia psicológica del cine alemán, Paidós, Barcelona, 1995.

- NANCY, Jean -Luc, La Comunidad inoperante, Ediciones LOM, Santiago, 2000.

- PAUWELS, Louis - BERGIER, Jaques, El Retorno de los brujos; una introducción al realismo fantástico, Editorial: Plaza y Janès, Barcelona 1963.

- $\quad$ SAFRANSKI, Rüdiger (1994), Un Maestro de Alemania; Martin Heidegger y su tiempo, Editorial Tusquets, Barcelona, p. 2007.

- $\quad$ SAFRANSKI, Rüdiger, "Los movimientos antisistema son los herederos del espíritu del romanticismo", En El CULTURAL, 2009.

- $\quad$ SLOTERDIJK, Peter, El desprecio de las masas. Ensayos sobre las luchas culturales de la sociedad moderna, Pre-textos, Valencia, 2001.

- SLOTERDIJK, Peter, Ira y tiempo. Ensayo psicopolítico, Editorial Siruela, Madrid, 2010. 